\title{
The Hybridity in the Rites of Passage among the Ewe Ethnic Society in the Kumasi Metropolis
}

\author{
*BONSU, Hannah Serwah KQUOFI, Steve ASANTE, Eric Appau \\ Dept. of Educational Innovations, CABE, KNUST, Kumasi, Ghana
}

\begin{abstract}
This study investigated the rites of passage of the Ewe ethnic society in the Kumasi Metropolis. It discusses the influence of the Asante host culture's rites of passage on the Ewe ethnic society's culture resulting in the hybridity of culture as a result of migration. The study was driven in a purely qualitative study with descriptive study as the study design. Thirty (30) study participants consisting of chiefs, elders in the traditional court and the elderly in the study area. Personal interviews and focus group discussions were the data collection tools used for collecting the data for the study. The findings of the study revealed that the Ewe cultural practices exhibited in the Kumasi metropolis is as a result of hybridity. The study contends that as the Ewes play their culture alongside the host culture-Asante culture, they consciously and unconsciously fuse and or substitute their indigenous culture which has virtually merged or replace their culture.
\end{abstract}

Keywords: Value, Rites of Passage, Acculturation, Enculturation, Ethnicity, Cultural Hybridity

DOI: $10.7176 / \mathrm{JCSD} / 62-01$

Publication date:October $31^{\text {st }} 2020$

\subsection{Introduction}

Migration is the movement of people across national boundaries (Nayyar, 2000). This has been increasing as a result of people seeking for better lives. As people move into a new place to settle, they go with their culture and play it alongside cultures that are already existing in the place. A specific migrant group's cultural practices and customs differentiate them from other people (Bhugra \& Becker, 2005). Many are the features that brings variation between the different cultural groups, but the most common ones are the forms of speech, belief system, history or ethnicity-real or imaginary as well as dress and decoration types (Mesoudi, 2019). There are three categories of migrants identified in the Kumasi Metropolis of Ghana. Following the Ghana Statistical Service classification of ethnic groups, the first two categories make up the Akan ethnic group. These are:

1. Migrants born elsewhere in the Ashanti region (62.0\%) that may be mostly Asantes.

2. Migrants born elsewhere in another region of Ghana - Western, Central, Eastern and Brong Ahafo regions. The people of these regions have similar cultural practices with the people in the research community- Kumasi. They belong to the Akan ethnic group and their number represent 82.4 percent of migrants in the Kumasi Metropolis.

3. The third category comprises migrants born elsewhere in Ghana, but not belonging to the Akan ethnic group. Among these are migrants from the Northern regions, the dominant being the Mole-Dagbani group. The Ewes from the Volta Region and Ga-Adangbe from the Greater Accra Region and part of the Eastern Region representing $5.8 \%$ of the population while other ethnic groups mostly Gurusi, Guan, and Gurma ethnicity comprise $1.9 \%$.

The differences in cultural display by migrants therefore creates a situation which affects the migrant's identity in becoming recognised in the new place of settlement as members of the community. The situation migrants find themselves lead them to psychological test which affects their emotional, media and policies responses (Agadjanian, 2005; Arango et al, 2005). Dynamics such as technology and education have been argued to alter migrant psychologically (Berry, 1997; Phinney, Horenczyk, Liebkind, \&Vedder, 2001). They further explained that migration leads to a huge exchange that has as association the individual concepts, goods and other aspects of culture termed as hybridity, which in turn lead to new ties and trends (Pieterse, 1994).

In the Kumasi Metropolis, the "host" ethnic group, is the Akan and the 'migrant' ethnic groups are the MoleDagbani, Ewe, Ga-Adangbe and all others. Therefore, it can be seen that there is an enormous amount of ethnic and cultural diversity in the metropolis but, they are in close harmony. However, the fact remains that the Asante culture is the most visible and prominent culture in the Kumasi metropolis hence the dominant or host culture to other migrant ethnic groups (Arthur, 2009). There is therefore a high rate of acculturation in a culturally diverse environment. In most cases, the host or dominant culture shapes or influences the migrant cultures. This makes it difficult for migrant ethnic groups to stay away from the influence of this predominant Asante Culture.

When the predominant culture and other influential cultures come into contact with migrant's culture, there is a fusion or total neglect of the migrants' culture, resulting in hybridization. The main features that identify people with the theory "hybrid identities" is that, neither the beliefs and culture nor the place of residence in totality reflect the migrant's home of origin. In hybridization, culture and identity are directly related and the identity of the people are habitually and unswervingly affected (Ashraf, 2017). Using the hybrid identity theory (Kraidy, 2005) 
as a premise, the assumption is that there is a high rate of a new cultural identity formation among the migrant ethnic groups in Kumasi. As the migrant groups interact with the host group, their cultural identities are assumed to undergo regular change. This results in a new cultural identity, which is a blend of the host culture and the migrant culture (Bonsu, 2010).

Therefore this study focuses on the effects of the other cultures in the rites of passage and their influences on the identity of Ewe migrant settlers within the Kumasi metropolis. The research assessed the phenomena of hybrid identity formation by identifying the elements of host cultural practices within which hybrid identity formation has emerged (e.g. rites of passage etc.) and how the convergence in the daily life of two cultural history. The study examines the extent to which the adoption of these cultural elements of the host culture (rites of passage) has affected the cultural identity of Ewe migrants in the Kumasi Metropolis.

\subsection{Literature Review}

\subsection{The Ewe Ethnic Group}

The Ewe are originally inhabited in the southeast corner of Ghana - east of the Volta River in the Volta region, territories extending to Togo and Benin. Ewe is a major dialect belonging to the Gbe family of Niger-Congo. The Vedome people occupies the central part of the Volta region and are known to be mainly weavers of the Kete cloth; The Tongus are sited along the stretch of the Volta Lake who are engaged in fishing in the river whereas the Anlos are located at the coastal belt along the Gulf of Guinea and are also fishermen. The Vedome (Deyi), Tongu, Mina, Aneoho and the Anlo Ewe people constitute the sub groups in the Ewe ethnic group of Ghana, (Duthie, 1988). The type of inheritance found among the Ewe is purely patrilineal. Among the Anlo Ewe, personal property, landed or otherwise acquired passes from father to sons and daughters. As a rule, sons take precedence over daughters, though the latter are not entirely excluded from the share.

The Ewe people have developed the complex culture around drumming, dancing, weaving and farming. The traditional Ewe religion is the Voodoo, which in the Fon language means spirits. Christianity, Islam and the other religions have followers among the Ewe ethnic group, yet the traditional religious rituals of their ancestors still hold supreme.

\subsection{The Concept of the Rites of Passage}

The significant revolving stages of human development is referred to as rites of passage (Nukunya, 1988). It includes birth, puberty, marriage and death. These stages involve rituals and informal teachings that may be real or psychological. At birth, the new born is welcomed into the family, community and the world of the living at large. This is not observed and cannot be acknowledged by the child in question until he or she is grown and made aware. Puberty and marriage rites are observed by initiating the individual who witnesses all the activities. These two rituals are performed to honour the initiating individual and his or her family. Death is the transition of a person from the living to join his or her ancestors in the land of hereafter. Special and significant rituals are performed no matter the status or background of the deceased in the community he/she hails from.

Though the world has been through a lot of reforms and changes since its creation and settlements, rites of passage among Africans especially the people of the Volta region of Ghana, the people still have the salient concepts maintained in diverse forms in their culture.

\subsection{The Indigenous Rituals in the Rites of Passage among Ewe's of Ghana}

\subsubsection{Naming Rites}

A naming ceremony among the Ewe is known as Vinehedego, which literally means 'outdooring a baby'. On the arrival of the baby, he or she is called amedzro - a stranger (Duthie, 1988). Among the Ewes, the first name of the child corresponds with the day name he or she was born to wait on the actual name which will be based on the child's character. It takes place on the eighth day of the birth of the child. An example is that, if a child is born on Monday, he/she will be called Kojo or Adjo for a boy or a girl respectively.

The actual naming ceremony brings together both families of the father and mother of the newly born child, friends and well-wishers who gather together in the family house of the father to perform the rituals. The ceremony is performed by a good moral standing elder who may be from the child's paternal family or the community. The ceremony begins with the performing of libation and the mentioning of the child's name for three conservative times after which water is sprinkled on the named child. The child is given sugar to taste after which an alcohol drink, schnapps gin, is dropped on the tongue of the child if it is a boy. The significance of this act is to instil truthfulness and consciousness in moral development of the child. Also other names are added onto the child's name based on the occurrences in the time of delivery, the occasion or an incident. Further presentations are given to the child and in some instances some parents are given to the mother amidst merry making. It is important to note that drinks made from corn and the local alcoholic gin, akpeteshie are served to mark the end of the cerebration. 2.3.2 Puberty Rites

This is one ritual that is not conspicuously honoured among Ewes in the Volta regions in Ghana. At the adolescent 
stage of both boys and girls, special attention is given to them. This age period is significant because parents involve their children in adult life activities- caring for younger siblings, cooking, farming, fishing, and in some cases construction of homes for the family (Tzanelli, 2011). The involvements in afore mentioned activities by the teens, depends on the family. The men are involved in community work, war and also going for hunting. Ewe adolescent girls are on the other side taught on how to keep themselves. They are taught by their mothers on how to maintain their womanhood, care for their future husbands and children. This is to ensure continuity when the aged are no more. Also, this is done to pass on the branded activities and behaviours from one generation to another. 2.3.3 Marriage Rites

Young adults who have attained marriageable age look up to their parents to offer the right advice on their potential couples and probably select their life partner for them (Salet, 2018). This is to ensure the safety of not going for any woman or woman whom the family would not support. Also marrying from the same lineage is considered as taboo.

Marriages among Ewes are spearheaded by the parents of the would-be partner. The choice of any member for a spouse is influenced by the ties of both families. Even if the man is in particular lady, he talks to the woman initially only to establish an acquaintance with her until his father is consulted and gives his approval. On expressing his interest to his father - the father goes ahead to communicate it to the woman's family after his investigations. The official marriage proposal is made through the lady's aunts to parents using a pot of palm-wine. On acceptance by the lady's parents after seeking her consent, a locally brewed gin Akpeteshie and money is sent to the would-be wife's parents as knocking fee - vuofofo. All the listed marriage items sronu, or the marriage ceremony to her family's specification is given to the would-be-groom's parents. Usually the list comprises of the would-be-wife's personal wears in a bag, assorted drinks for the occasion including schnapps and moneys to the in-laws.

On the day of the ceremony, the sronu is presented to the wife-to-be in her father's house. The paternal and maternal aunts of the bride inspect the items and when it is set for consummation, which is referred to as dodoadadzi proceeds. The bride dresses in Ewe traditional cloths. Libation is performed to ask their ancestors to bless the marriage. The groom and the bride's aunts take the wife to her father-in-laws house where the family would welcome her warmly. The father of the groom receives her, advice is given to the new couple and a concluding libation is performed. This prayer is to thank the gods and ancestors for a successful marriage ceremony and ask for their protection and peace for the newly married couple. Women are married into their husband's home since they uphold the patrilineal system of inheritance. This makes the woman part of the man's family. Also, children born to the woman inherit from the father.

\subsubsection{Death Rites}

Death is the last stage of the cycles of human life and the first in getting to one's ancestors. It is the full responsibility of the elder of the family to take full charge of all rituals and activities that serve to seal the back of the dead from the land of the living (Daniel, 2009). If the death is surrounded with issues, consultations are made to ensure safe and peaceful burial of the deceased. He sees to the performance of libation before the body is kept awaiting the day for burial. It is usually the elderly women in the community who use herbs to preserve and ensure the safe keeping of the body. Plans of how the funeral rites will be performed is concluded by the elder of the family in collaboration with the funeral committee in accordance with the protocols of the community.

The financial capacity is not embedded on any individual or a set of people. It is the total responsibility of the whole family and the community at large. Members contribute towards the funeral as records are kept. In the course of the preparation, if there is the need for more funds, members are recalled and further contributions are made. The rituals are surrounded with performance of libation, drumming and dances. One of the major dances displayed is the Agbekor which used to be a war dance but now used to retell the life of the deceased. This dance also elevates the dead to one of his/her ancestors. Colourful traditional cloths are worn by both mourners and dancers. The dancing activities grace the ceremony not in mourning atmosphere as presumed in other cultural burial ceremonies in the country.

After the burial, accounts are made to reconcile the contributions made by members in the family and the community with the donations made by sympathisers. Members who contributed for the ceremony may collect their moneys back if there is not any debt incurred. Instances where debt is incurred, those willing to defray it will opt not to take their moneys to clear the deficit. A successor is selected by the family head and the person should come from the patrilineal root.

\subsection{Methodology}

The main approach used is qualitative as defined by Corbin and Strauss (1990), as any form of study generating results that are not obtained by statistical analysis or other quantification methods. The researchers adopted a descriptive survey in the form of cross-section for this study. Descriptive study shows how things were related to each other naturally (Blumberg, Cooper \& Schindler, 2005). Descriptive studies cannot, however, explain why the event occurred and is well suited for a relatively new or unexplored field of research (Punch, 2005). The reason 
why the researchers used this method was to find out how other culture influences and affects that of migrants in a new destination. This, as in hybridity, has been constructed, negotiated and expressed through the channels of transformation, adaptation and erosion. Secondly, to obtain first-hand information from respondent the researcher needed to select a method which would enable her formulate a credible and informed conclusion for the study. Also, it gives a clear picture of the perception and actions of individuals and attempts to clarify the data gathered at a particular time. According to Fraenkel and Wallen (2000), descriptive research is versatile and practical, especially to the administrator. The population for the study comprised of the Ewes at Anloga in the Kumasi metropolis in the Ashanti region of Ghana. In selecting respondents, purposive sampling was taken of which thirty (30) respondents were selected. Personal interviews and focus group discussions were used for collecting the data. Focus group discussions were much more appropriate because the study focused solely on the ethnic group chief, elderly men in the traditional cabinet as well as elderly women. These data collection instruments aided in generating the right data in answering the research questions.

Responses to the interview questions were more informative due to its deeper explanation into the research area. Thematic data analysis was used to interpret the phenomenon by defining the key element in the phenomenon and also to categorize the relationships between them in the context and the study procedure.

\subsection{Results and Discussion}

\subsection{Naming Rites: Hybridity of the Cultures of the Ewe and Asante Ethnic Societies}

According to the chief, the representative of the Ewe ethnic group in the Ashanti region, naming ceremony of a child at their new place has changed dramatically and makes it difficult to even make up some of the youth to be Ewes just by their name(s).It was realized that naming now among Ewes in the Kumasi metropolis does not conform to the principle of their people and culture back 'home' but who the father of the unborn child decides to; 1) which may be based on the people around him as a family member who has contributed to his life; 2) an in-law who may or may not be an Ewe but might have taken him/her (the Ewe spouse) to be his/hers; and 3) bosses at the work place, landlords and in some cases their religious leaders. The Ewe father of the newly born child in the region, solely decides whom to name his child after. He then informs his parents some elderly people amidst his close relations and friends to perform the naming ceremony. This has resulted to having names like Mawuli Dennis, Patience Akosua Serwah, Enyonam Abass and the like being Ewes in the metropolis.

The rituals a child goes through as an Ewe vary. According to the Personal Communicators $1 \& 2$, it is established that naming ceremonies are performed alright but the process, material and in some cases the rituals are completely not as the Ewe tradition demands.

Traditionally, a child born is supposed to be named on the seventh or the eighth day after delivery. But in the Ewe community in the metropolis, there are instances a child is named formally on the fortieth to the ninetieth day after delivery. The delay in naming a child has been as a result of the unplanned family creation on the part of either one or both of the new parents who are usually not married couple. Also, children born into the Ewe family in the metropolis are named by religious leaders based on the belief of the parents - Christianity/Islam, Buddhism among others. In this case the process in naming a child is based on the religious group rather than the Ewe tradition.

\subsection{Puberty Rites: Hybridity of the Cultures of the Ewe and Asante Ethnic Societies}

Most of the Ewe youth settlers were born in the Kumasi metropolis have little or no idea about puberty rites before marriage among their ethnic group members. They have knowledge of some other cultures practicing the rituals in the puberty rite and regarded the practice as obsolete. Ewe parents are very close to their adolescent children and train them in gender roles. Male children usually follow their fathers and other male adults in the family who are role models to learn occupation, to enable them fend for themselves. Girls on the other hand, pay heed to their mothers and other female role models to emulate the salient roles as well as their exemplary lifestyle.

The effort to train their children to inherit the Ewe culturally accepted way of life, these growing children in the metropolis emulate lifestyles they are more comfortable with not necessarily based on their culture. Nowadays, the lifestyle the youth emulate is based more on lifestyles they consider to be the modern trends as a result of lifestyles showcased in social media and several other modern technologies. They, however, refer to their cultural elements as "old fashion"

\subsection{Marriage Rites: Hybridity of the Cultures of the Ewe and Asante Ethnic Societies}

Marriage is an important stage in the life of traditional Ewes. However, marrying from other ethnic groups not considering issues relating to inheritance is limiting the Ewe people in widening the lineage in the Kumasi metropolis. Though, Ewes do not discriminate in choosing a partner for marriage, a good choice is considered paramount. If an Ewe man or a woman wants to marry from other cultures but the man comes from an ethnic group which is matrilineal, the child ends up losing at both sides in inheritance. A child or children born to a man to any ethnic group does not and cannot inherit from the Ewe ethnic group. Hence an Ewe woman who marries a man who inherits from the matrilineal lines also keep the children. This has a negative ramification as far as inheritance 
is concerned. Children born to both parents who can inherit from both parents are of advantage and can decide where to belong. Based on the revelations of the life pattern of the Ewes in the Kumasi metropolis to be, many of the Ewe ethnic members have ended up culturally aligning to the ethnic group they feel comfortable with, notably the Asantes.

Though proposed couples may be from different ethnic groups, the process of marriage seem not to have much differences. This is because, from all ethnic groups in Ghana, a man proposes to a woman and on acceptance, the father of the woman gives his daughter in hand to a marriage. This connotes that, all items to be presented on the day of final marriage ceremony are determined by the father of the woman. Therefore, Ewes who are in the Kumasi metropolis have no problem marrying from other ethnic groups. It is important to note that a daughter is into marriage by the father and then collects the bride-price, as oppose to a son getting marriage to a woman of his choice. In this case the father of the woman does the collection of the bride-price and other presentations from the man's family members as tradition demands. The woman being given into marriage subsequently becomes part of her husband's family after the marriage rites. It is very paramount to indicate that respect due every member of the man's family is expected to be accorded by the woman.

Lastly, among the Ewes, child bearing is one of the main reasons for giving a woman to a man to marry. Any delay in having a child result in bringing a lot of marital frictions between the couple and their families which subsequently compelled the man to take a second wife or giving birth outside marriage. Every member of both families play a significant role in the sustenance of the marriage.

\subsection{Death Rites: Hybridity of the Cultures of the Ewe and Asante Ethnic Societies}

Funeral is the final stage of the rites of passage which seeks to usher every individual to the land of the dead, etsiofe. This belief of the dead joining his/her ancestors makes the ceremony very important and memorable. Though the person may or may not have lived as an Ewe due to some circumstance(s), yet every individual who has a role to play as an Ewe and a family member will have to ensure all rites to be performed are done to specification.

On the occurrence of death, the close associates and the family of the deceased if around, will immediately go and inform the Ewe representative in the locality and or the chief of the Ewes in the metropolis with an alcoholic beverage, preferably a gallon of local spirit - akpeteshie. With the consent of the ethnic elder, enunola, in the metropolis and the family, plans for the pre-funeral rites are made and circulated to all family and ethnic members far and near. The day set for the final funeral rite depends on the agreement of the family, elders and the dead's religious leaders in the community. There is no fixed day in holding final funeral rites among the Ewes in the Kumasi metropolis. Any day in the week is a preference.

\subsection{Conclusion}

The research established that Ewes residing in the Kumasi metropolis practice their culture to feel comfortable showcasing it in their new environment, hence hybridity. Hybridity has become a symbol of the transformations of cultures. The concept of hybridity is also synonymous with cultural fusion and difference. According to Kraidy (2005: 8) it resonates "with the globalization mantra of unfettered economic exchanges and the inevitable transformation of all cultures". According to Garcia-Canclini (1989:11) Hybridity "includes diverse intercultural mixture and includes the modern forms of hybridization". In the current globalization era individuals, communities, countries and continents have been compelled to adopt foreign cultures in order to fit into the global world. During such period of adoption, an intermingling of cultures develops during which new cultures are created.

The Ewes in the Kumasi Metropolis have come face to face with the issue of hybridity as their mode of cultural practices have consistently been undergoing transformations. The real nature of cultural practices by this ethnic group has undergone several changes consciously or unconsciously within itself in the Kumasi Metropolis. Although there may be a slight or a complete neglect of the culture practiced at their home of origin, the study sought to give a consideration and acceptance as hybrid. This results into the 'New Culture'- hybrid practices then becomes the bridge to put two cultures together as one. This could be appreciated when the hybrids are displayed openly with the original for others to appreciate and to understand them better. This enables the host to deepen their understanding of how and why the migrants showcase such cultural practices in order to prevent marginalization. Therefore, there is the need to highlight the Ewe culture in the metropolis and to create interconnection to fit into the growing globalization the entire world is advocating.

\section{References}

Agadjanian, V. (2005). Gender, religious involvement, and HIV/AIDS prevention in Mozambique. Science \& Medicine

Arango, J. \& Jachimowiecz, M. (2005). Regularizing Immigrants in Spain: A New Approach. Migration Policy Institute

Arthur, N.A.P. (2009). The Role of Performing Arts in Asante Culture. PhD African Art and Culture Thesis, 
Department of General Art Studies, K.N.U.S.T., Ghana

Ashraf, M. A. (2017). Cultural Hybridization in the Globalized China: A Case Study of Young University Students. Int. Commun. Chin. Cult., 4, 457-465

Assimeng, M. (1992). Religion and Social Change in West Africa. Cambridge University Press: October 1992, pp. $581-583$

Berry, J. W. (1997). Immigration, acculturation, and adaptation. Applied Psychology, 46(1), 534.

Berry, J. W. (2003). Conceptual approaches to acculturation. In K. M. Chun, P. B. Organista, \& G. Marín (Eds.), Acculturation: Advances in theory, measurement, \& applied research (pp. 17-37). Washington, DC: American Psychological Association.

SBhugra, D. \& Becker, M. A. (2005). Migration, Cultural Bereavement and Cultural Identity. World Psychiatry, 4(1): $18-24$

Blumberg, B., Cooper, D. R. \&Schindler, P. S. (2005). Business research methods. McGraw Hill. Berkshire

Bonsu, H.S. (2010). "Promoting Local Development in Atwima Nwabiagya through a Hybrid of Cultures". Unpublished Masters' Theses, Kwame Nkrumah University of Science and Technology: Kumasi. Ghana.

Castro, V. S. (2003). Acculturation and psychological adaptation. Westport, Connecticut: Greenwood Press.

Corbin, J. M. and Strauss, A. (1990). Basics of qualitative research: Grounded theory procedures and techniques. Thousand Oaks, CA, US.

Daniel, K. (2009). An Analysis of the Rites of Passage and their Relation to Christianity. Int. Journal of Sociology and Anthropology, 1(8): 156-166

Duthie, A. (1988). Ewe In: The Languages in Ghana, E. M. Kropp-Dokubu (Ed.) KPI, London.

Farver, J. M., Bhadha, B. R. \& Narang, S. K. (2002). Acculturation and psychological functioning in Asian Indian adolescents. Social Development, 11, 11-29.

Fraenkel, J. R. and Wallen, N. E. (2000). How to design and evaluate research in education. New York: McGraw Hill Inc.

Gordon, M. (1978). Human nature, class, and ethnicity. New York: Oxford University Press.

Graves, T. D. (1967). Psychological acculturation in a tri-ethnic community. Southwestern Journal of Anthropology, 23, 336-350.

Garcia-Canclini, N. (1989). Hybrid Cultures: Strategies for Entering and Leaving Modernity Lucaya Books Stores. Herskovits, M. J. (1948). Man and his Works: The Science of Cultural Anthropology. New York: Knopf, 1948.

Kraidy, M. (2005) Hybridity or the cultural logic of Globalization. Temple University Press.

Kim B. S. K. \& Abreu J. M. (2001) Acculturation measurement: Theory, current instruments, and analysis

Kim, B. S. K. (2007). Acculturation and enculturation. In: Leong FTL, Inman AG, Ebreo A, Yang L, Kinoshita L, Fu M, eds. Handbook of Asian American Psychology, 2nd ed. Thousand Oaks, CA: Sage, 2007: pp. 141158.

Mesoudi, A. (2019). Correction: Migration, Acculturation, and the Maintenance of Between Group Cultural Variation. PLoS ONE, 14(4): e0216316

Nayyar, D. (2000). Cross-border movements of people. Working papers, No. 194. UNU World Institute for Development Economic Research

Nukunya, G. K. (1975). The family and Social Change in M. Owusu (Ed) Colonialism and Change. Essays Presented to Professor Lucy Mair, The Hague, Mouton.

Nukunya, G. K. (1988). Kinship and Marriage among the Ewe, London School of Economics, Monographs on Social Anthropology, London, Athlone Press.

Nukunya, G. K. (2003). Traditional Change in Ghana: An introduction to sociology, second edition. Accra: Ghana University Press.

Nukunya, G. K. (2013). Tradition and change in Ghana: an introduction to sociology: Teach yourself senior high school social studies. Stanford Libraries.

Phinney, J. S., Horenczyk, G., Liebkind, K. \& Paul, V. (2001). Ethnic identity, immigration, and well-being: An interactional perspective. Journal of Social Issues, 57(3), 493-510.

Pieterse, J. N. (1994). Globalisation as hybridisation. International Sociology, 9(2), 161-184.

Salet, W. (2018). Sifting Through Transition: Revisiting 'Rites of Passage'. Transactions of the Association of European Schools of Planning, 2: 1-8

Szapocznik, J., Scopetta, M., Kurtines, W. \& Aranalde, M. (1978). Theory and measurement of acculturation. Interamerican Journal of Psychology, 12, 113-130.

Tzanelli, R. (2011). Rites of Passage IN: Ritzer, G. \& Ryan, M. J. (Eds.). Concise Encyclopedia of Sociology. New Jersey: John Wiley and Sons

Weeks, L. (2002). Frappe society: The trend to blend. Washington Post, pp. C1-C2.

Zapf, W. (2003). Modernization Theory-and the Non-Western World. Paper presented to the conference "Comparing Processes of Modernization", University of Potsdam, December 